Chia-Hsiang Chen • Wen-Yu Chen • Hui-Lin Liu

Tze-Tze Liu • Ann-Ping Tsou • Ching-Yuang Lin

Ting Chao $\cdot$ Yu Qi $\cdot$ Kwang-Jen Hsiao

\title{
Identification of mutations in the arginine vasopressin receptor 2 gene causing nephrogenic diabetes insipidus in Chinese patients
}

Received: July 4, 2001 / Accepted: December 4, 2001

\begin{abstract}
Congenital nephrogenic diabetes insipidus (NDI) is, in most instances, a rare $\mathrm{X}$-linked recessive renal disorder (MIM 304800) characterized by the clinical symptoms of polyuria, polydipsia, and dehydration. The X-linked NDI is associated with mutations of the arginine vasopressin receptor type 2 ( $A V P R 2$ ) gene, which results in resistance to the antidiuretic action of arginine vasopressin (AVP) in the renal tubules and collecting ducts. Identification of mutations in the AVPR2 gene can facilitate early diagnosis of NDI, which can prevent serious complications such as growth retardation and mental retardation. We analyzed three unrelated Chinese NDI families and identified three mutations: R106C, F287L, and R337X. In addition, an A/G
\end{abstract}

\section{C.-H. Chen}

Department of Psychiatry, Tzu-Chi General Hospital and Tzu-Chi

University, Hualien City, Taiwan

W.-Y. Chen · T.-T. Liu • K.-J. Hsiao

Institute of Genetics, National Yang-Ming University, Taipei,

Taiwan

H.-L. Liu · K.-J. Hsiao ( $\square)$

Department of Medical Research and Education, Taipei Veterans

General Hospital, Peitou P.O. Box 2-207, Clinical Biochemistry

Research Laboratory, Taipei 11216, Taiwan

Tel. +886-2-28757401; Fax +886-2-28733517

e-mail: hsiao@mail.pmf.org.tw

A.-P. Tsou

Institute of Biotechnology in Medicine, National Yang-Ming

University, Taipei, Taiwan

C.-Y. Lin

Department of Pediatrics, Taipei Veterans General Hospital, Taipei,

Taiwan

C.-Y. Lin

Institute of Microbiology and Immunology, National Yang-Ming

University, Taipei, Taiwan

T. Chao

Chao-Ting Pediatric Clinic, Taipei, Taiwan

Y. Qi

First Hospital of Peking University, Beijing, PRC

K.-J. Hsiao

Genome Research Center, National Yang-Ming University, Taipei, Taiwan polymorphism at cDNA nucleotide position 927 (codon 309L) was identified. A functional expression assay of the R106C and F287L mutants in COS-7 cells revealed that both mutants show significant dysfunction and accumulate intracellular cyclic adenosine monophosphate in response to AVP hormone stimulation. These results facilitate the diagnosis of NDI at the molecular level in the Chinese population, and provide insight into the molecular pathology of NDI.

Key words Vasopressin receptor gene - Mutation - Polymorphism - Nephrogenic diabetes insipidus - Chinese . Functional expression

\section{Introduction}

The vast majority of congenital nephrogenic diabetes insipidus (NDI) cases have been shown to be due to a rare X-linked recessive genetic disease (MIM 304800), which results from an impaired response of the distal renal tubule cells and collecting ducts to the antidiuretic action of arginine vasopressin (Bichet 1994, 1998). Although female carriers usually only show mild symptoms, affected male patients usually present, soon after birth, with much more severe clinical symptoms, including polyuria, polydipsia, dehydration, fever, vomiting, and failure to thrive. Unless recognized and treated early, persistent severe dehydration may lead to growth and developmental delay or death (Hoekstra et al. 1996), whereas, with appropriate treatment, the prognosis for NDI is usually good. Hence, early diagnosis and treatment is essential for affected families. Recent molecular genetic studies have demonstrated that the insensitivity of the renal tubule cells to arginine vasopressin (AVP) is associated with mutations of the arginine vasopressin receptor type 2 (AVPR2) gene (Birnbaumer et al. 1992; Lolait et al. 1992; Rosenthal et al. 1992).

$A V P R 2$ is encoded by a single gene that has been mapped to chromosome Xq28 (Kambouris et al. 1988; Van den Ouweland et al. 1992). The gene comprises three exons, 
spanning approximately $2 \mathrm{~kb}$ (Seibold et al. 1992). The gene encodes a 371-amino acid $\mathrm{G}$ protein-coupled receptor that has seven transmembrane domains, four extracellular domains, and four cytoplasmic domains (Birnbaumer et al. 1992; Lolait et al. 1992; Rosenthal et al. 1992). On binding of AVP, the receptor activates the Gs/adenylate cyclase, and this leads to the increased level of the intracellular cyclic adenosine monophosphate (cAMP). The elevated cAMP activates protein kinase $\mathrm{A}$ and starts a phosphorylation cascade that promotes the translocation of the water channel, aquaporin 2, to the apical membrane of the renal tubules and collecting tubules. This results in increasing water resorption (Sadeghi et al. 1997). To date, more than 100 mutations have been identified in the AVPR2 gene that cause NDI, including point mutations, deletions, and rearrangement. This indicates that there is a high level of genetic heterogeneity in the mutations that cause X-linked NDI (Bichet et al. 1994; Cheong et al. 1997; Fujiwara et al. 1995; Schoeneberg et al. 1998).

The availability of the entire $A V P R 2$ genomic sequence has facilitated mutation identification by polymerase chain reaction (PCR)-based autosequencing. In this study, we analyzed the $A V P R 2$ gene in three unrelated Chinese NDI families and identified three $A V P R 2$ mutations: R106C, F287L, and R337X, one of which, F287L, is novel. Because no functional characterization of the mutants of R106C and F287L has been reported, the mechanism by which these mutations cause NDI was investigated in a mammalian cell system. The identification of $A V P R 2$ mutations in these Chinese families should facilitate early diagnosis and early prevention of the complications of NDI in affected families of this racial group. The characterization of the mutants should bring new insight into the molecular pathology of NDI.

\section{Patients}

Patients and clinical diagnosis

Three unrelated families with NDI were referred by pediatricians. Two of the families were from Taiwan and one was from mainland China. The pedigrees are illustrated in Fig. 1.

Family 1. The index patient manifested vomiting, slight dehydration, and fever at 2 years of age. He was hospitalized under the preliminary diagnosis of a upper respiratory infection but was found later to have polyuria and polydipsia. Sonography revealed bilateral nephrocalcinosis. The urine and plasma osmolarity and the plasma electrolytes were within a normal range. However, a water deprivation test confirmed the diagnosis of NDI in this patient.

Family 2. The index patient developed fever, dehydration, polyuria, and polydipsia soon after birth. He was found to have hypernatremia $(150-160 \mathrm{mEq} / \mathrm{l}$, normal reference
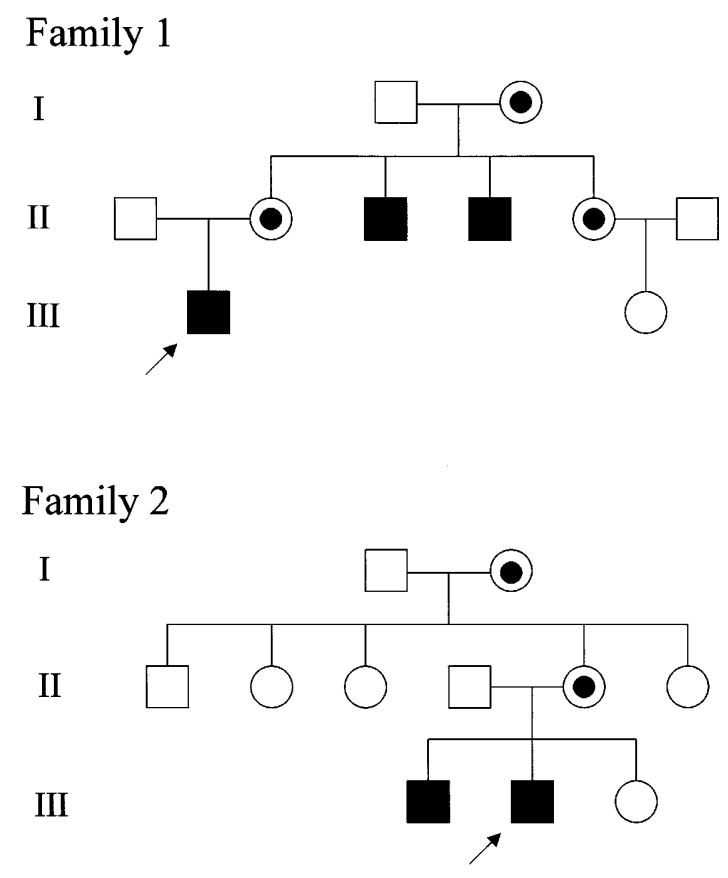

Family 3

I

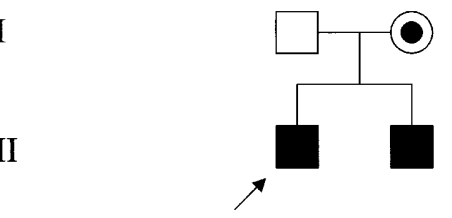

Fig. 1. Pedigrees of three Chinese families with X-linked congenital nephrogenic diabetes insipidus (NDI). Arrow denotes the index patient, solid squares are affected males, solid circles within open circles are heterozygote females determined by DNA sequencing

ranges: $130-150 \mathrm{mEq} / \mathrm{l})$, hyperchloremia $(120 \mathrm{mEq} / \mathrm{l}$, normal reference ranges: $98-106 \mathrm{mEq} / \mathrm{l})$, high plasma osmolality (320 mOsm $/ \mathrm{kg}$, normal reference ranges: $280-290 \mathrm{mOsm} /$ $\mathrm{kg})$, and low urine osmolality $(83 \mathrm{mOsm} / \mathrm{kg}$, normal reference ranges: $300-1000 \mathrm{mOsm} / \mathrm{kg}$ ). The patient's elder brother was also found to have polyuria and polydipsia but with milder clinical manifestations.

Family 3. The index patient from mainland China was hospitalized at 7 years of age with clinical symptoms of polydipsia and polyuria. He was found to have had a fever and a convulsion episode 3 months after birth. Since then, he was found to have polydipsia, polyuria, intermittent fever, irritability, growth retardation, and developmental delay. His younger brother was found to have similar symptoms. The clinical diagnosis was NDI. A blood sample was collected on filter paper, air dried, and mailed to this laboratory. The exonic regions of $A V P R 2$ gene were PCR amplified using genomic DNA extracted from the dried blood spot collected on filter paper (Hong et al. 1999). 
Detection of $A V P R 2$ gene mutations by

direct PCR sequencing

Genomic DNA was extracted from the peripheral white blood cells using the standard method or amplified directly from the dried blood spots collected on filter paper (Hong et al. 1999). All three exons and their flanking intronic sequences were PCR amplified using primer sets listed in Table 1 . The PCR primers for exon 1 and 3 were also used as sequencing primers. Four additional internal primers were designed for sequencing exon 2 because of its long sequences. The sequences of these internal primers are also listed in Table 1, and the locations of these primers in the $A V P R 2$ gene are illustrated in Fig. 2. PCR was performed in a volume of $100 \mu \mathrm{l}$ containing $0.5 \mathrm{mg}$ genomic DNA, $1.5 \mathrm{mM}$ $\mathrm{MgCl}_{2}, 50 \mathrm{mM} \mathrm{KCl}, 10 \mathrm{mM}$ Tris- $\mathrm{HCl}(\mathrm{pH} 8.3), 0.2 \mathrm{mM}$ deoxyribonucleoside triphosphates, $5 \mathrm{U}$ Prozyme Taq polymerase, $10 \%$ dimethylsulfoxide, and $1 \mu \mathrm{M}$ of each primer. PCR amplification of exon 1 was performed with an initial denaturation at $95^{\circ} \mathrm{C}$ for $5 \mathrm{~min}$, followed by 30 cycles of $95^{\circ} \mathrm{C}$ for $1 \mathrm{~min}, 59^{\circ} \mathrm{C}$ for $1 \mathrm{~min}$, and $72^{\circ} \mathrm{C}$ for $1 \mathrm{~min}$. For exon 2 and exon 3 PCR amplification, the annealing temperature was optimized to $63^{\circ} \mathrm{C}$. After PCR amplification, the PCR products were fractionated in $2 \mathrm{~g} / \mathrm{dl}$ agarose gel by electro- phoresis and purified from the sliced gel. The purified PCR products were subjected to direct sequencing using $\mathrm{ABI}$ autosequencer 377 (Perkin Elmer Applied Biosystem, Foster City, CA, USA). The ABI Prism BigDye Terminator Cycle Sequencing Ready Reaction Kit (Perkin Elmer Applied Biosystem) was used for the sequencing reaction according to the manufacturer's protocol.

PCR-based genotyping by restriction analysis

For genotyping R106C, 30 cycles of amplification were carried out at $94^{\circ} \mathrm{C}, 1 \mathrm{~min} ; 63^{\circ} \mathrm{C}, 1 \mathrm{~min}$; and $72^{\circ} \mathrm{C}, 1 \mathrm{~min}$ using standard PCR mixtures with sense primer NDIX2-S and antisense primer NDIX2-1A (Table 1). Aliquots of PCR products $(669 \mathrm{bp})$ were digested with $D s a \mathrm{I}$ overnight at $55^{\circ} \mathrm{C}$ incubation. After restriction digestion, the products were subjected to electrophoresis in $2.5 \mathrm{~g} / \mathrm{dl}$ agarose gel. The $\mathrm{R}$ allele yields 361-bp, 132-bp, 121-bp, and 55-bp fragments, whereas the $\mathrm{C}$ allele yields 361-bp, 187-bp, and 121-bp fragments. For genotyping F287L, 30 cycles of PCR amplification were performed at $94^{\circ} \mathrm{C}, 1 \mathrm{~min} ; 63^{\circ} \mathrm{C}, 1 \mathrm{~min}$; and $72^{\circ} \mathrm{C}, 1 \mathrm{~min}$ using standard PCR mixtures with sense primer NDIX2-3S and antisense primer NDIX2-A (Table

Table 1. Primer sequences for polymerase chain reaction amplification of all three exons of the AVPR2 gene and for direct sequencing

\begin{tabular}{|c|c|c|}
\hline & Position & Primer sequences \\
\hline \multicolumn{3}{|l|}{ Exon 1} \\
\hline NDIX1-S & nt $14-23$ & 5'-CAGAGGCTGAGTCCGCACAT-3' \\
\hline NDIX1-A & nt 194-214 & 5'-ATTGGCAGCCTGGAGAGACAC-3' \\
\hline \multicolumn{3}{|r|}{ 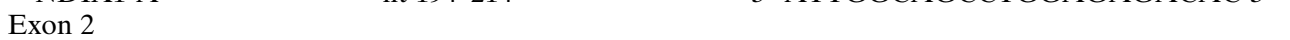 } \\
\hline NDIX2-S & nt $331-351$ & 5'-GCTTTCCTGGAGTCCCCTCTG-3' \\
\hline NDIX2-A & nt $1405-1424$ & 5'-GGGTTCAGGATGGCTGGTG-3' \\
\hline \multicolumn{3}{|c|}{ Sequencing primer } \\
\hline NDIX2-1S & nt $762-782$ & 5'-CTGTGTCGGGCCGTGAGGTAT-3' \\
\hline NDIX2-1A & nt $981-1000$ & 5'-ACCCCGCTGCCACCTTCCAC-3' \\
\hline NDIX2-3S & nt $1056-1076$ & 5'-ATTGCCCTGATGGTGTTCGTG-3' \\
\hline NDIX2-2A & nt $1405-1424$ & 5'-GCTGGGGCAGCACTTGGAACAG-3' \\
\hline \multicolumn{3}{|r|}{ 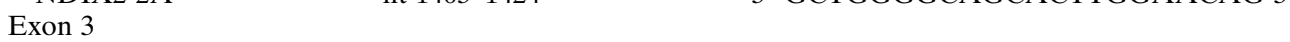 } \\
\hline NDIX3-S & nt $1396-1415$ & 5'-CCTGTGCCCCACCAGCCATC-3' \\
\hline NDIX3-A & nt $1702-1721$ & 5'-CCCAGGACCAGCCCCAGGAAG-3' \\
\hline
\end{tabular}

The reference sequence accession no. in GenBank is U04357

$\mathrm{S}$, Sense primer; A, antisense primer; nt, nucleotide

Fig. 2. Schematic diagram showing the genomic organization of the AVPR2 gene, primer locations for direct polymerase chain reaction-based sequencing, and the locations of mutations and polymorphism identified in this study $\begin{array}{lrr}\text { Exon } 1 & \text { Exon 2 } & \text { Exon } 3\end{array}$

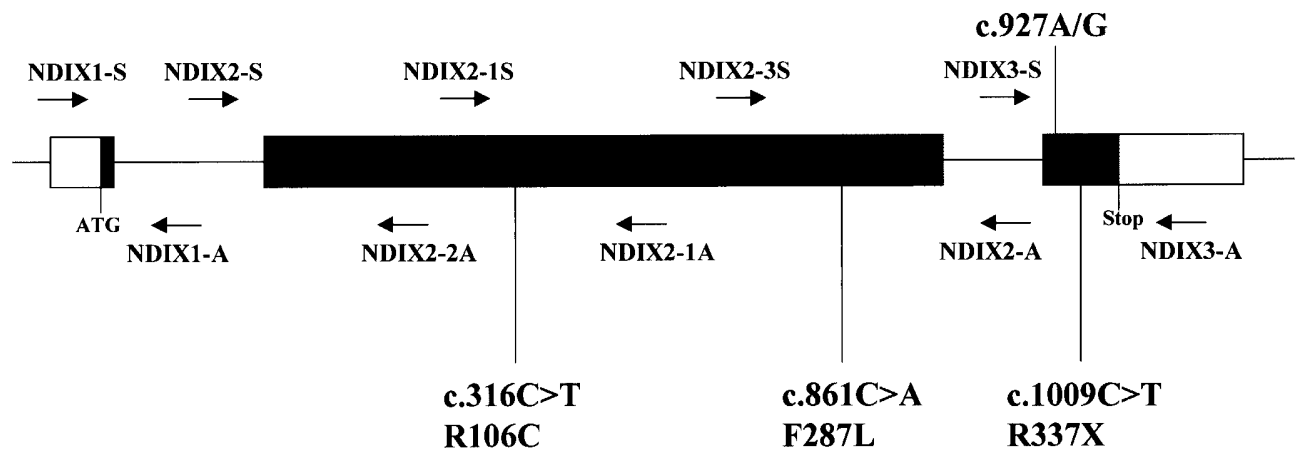


1). Aliquots of PCR products (367bp) were digested with Mbo II overnight at $37^{\circ} \mathrm{C}$ incubation. After restriction digestion, the products were subjected to electrophoresis in $2.5 \mathrm{~g} / \mathrm{dl}$ agarose gel. The $\mathrm{F}$ allele yields $177-\mathrm{bp}, 139-\mathrm{bp}$, and 51-bp fragments, whereas the $\mathrm{L}$ allele yields 316-bp and 51-bp fragments.

\section{Construction of mutant $A V P R 2$ cDNA}

The full-length human $A V P R 2$ cDNA in a eukaryotic expression vector, designated HA-hV2-pcD-PS, was kindly provided by Dr. Jurgen Wess (Laboratory of Bioorganic Chemistry and Metabolic Diseases Branch, National Institute of Diabetes and Digestive and Kidney Diseases, Bethesda, MD, USA). The construction of this plasmid has been described in detail elsewhere (Schoeneberg et al. 1996). The expressed $A V P R 2$ has a nine-amino acid tag, derived from influenza virus hemagglutinin to aid in the study of cellular localization. The R106C and F287L mutant cDNA constructs were generated using QuickChange Site-Directed Mutagenesis kit (Stratagene, La Jolla, CA, USA) according to the manufacturer's protocol. The authenticity of these expression constructs was verified by sequencing.

Transient eukaryotic expression and characterization of AVPR2 mutants

COS-7 cells were grown in Dulbecco's modified Eagle's medium (DMEM) supplemented with 10\% fetal calf serum at $37^{\circ} \mathrm{C}$ in a humidified $5 \% \mathrm{CO}_{2}$ incubator. For transfection, $10^{6}$ cells were seeded into $60-\mathrm{mm}$ dishes. About $24 \mathrm{~h}$ later, cells were transfected simultaneously with the mutant $A V P R 2$ constructs and a plasmid containing $\beta$-galactosidase cDNA using LIPOFECTAMINE Reagent Protocol provided by the manufacturer (Life Technology, Gaithersburg, MD, USA). Forty-eight hours after transfection, the cells were starved for another $24 \mathrm{~h}$ before adding AVP with different concentrations, $10^{-6}, 10^{-8}, 10^{-10}$, and $10^{-12} \mathrm{M}$, respectively. The reactions were stopped by adding $0.1 \mathrm{~N} \mathrm{HCl}$. The intracellular cAMP levels were determined by using the BIOTRAK cAMP $\left[{ }^{125} \mathrm{I}\right]$ assay system from the manufacturer (Amersham Pharmacia Biotech UK Limited, Little Chalfont, Buckinghamshire, UK). The protein concentrations were determined using the Lowry method, and $\beta$ galactosidase activity was also determined using a $\beta$-Galactosidase Assay Kit according to the protocol provided by the manufacturer (Stratagene).

\section{Results}

Identification of R106C, F287L, and R337X mutations in the $A V P R 2$ gene causing NDI

In family 1 , after sequencing the whole protein-coding region, a C-to-T transition was identified at nucleotide posi- tion 316 of the cDNA sequence, designated c.316C $>\mathrm{T}$. The alteration of the nucleotide sequence results in the substitution of arginine for a cysteine at codon 106 in exon 2 , designated R106C. The sequencing result is illustrated in Fig. 3a. The R106C mutation eliminates a $D s a \mathrm{I}$ restriction site, in the wild-type allele, which facilitates PCR-based restriction analysis for genotyping. The $\mathrm{R} 106 \mathrm{C}$ was found to cosegregate in the affected family members, and was not found in 50 apparently normal females.

In family 2 , a C-to-A transversion at nucleotide position 861 of the cDNA sequence was identified after sequencing the whole protein-coding region, designated c.861C $>$ A. The sequencing result of the proband is illustrated in Fig. 3b. The alteration of nucleotide sequence leads to a phenylalanine-to-leucine substitution at codon 287 in exon 2, designated F287L. The F287L mutation eliminates an MboII restriction site, which also facilitates PCR-based restriction analysis for genotyping (Fig. 4). This mutation cosegregates with the affected members in this family, and was not detected in 40 apparently normal females and 20 normal males.

In family 3, a C-to-T transition at nucleotide 1009 of the cDNA sequence was identified after completely sequencing the whole protein-coding sequence, designated c.1009C $>\mathrm{T}$ (Fig. 3c). The mutation results in a premature termination of the protein at codon 337 in exon 2 and was designated $\mathrm{R} 337 \mathrm{X}$. The younger affected brother was also found to have this mutation. This mutant was identified by sequencing in the mother, and the father does not have this mutation.

Identification of a c. $927 \mathrm{~A} / \mathrm{G}$ polymorphism of the AVPR2 gene

In addition, an $\mathrm{A} / \mathrm{G}$ polymorphism was identified at nucleotide 927 of the $A V P R 2$ cDNA sequence in family 1 (Fig. $3 d)$. Because the $A / G$ polymorphism does not alter a restriction enzyme recognition site, 100 chromosomes were sequenced to determine the allele and genotype frequency in the Chinese population in Taiwan. The allele frequencies of $\mathrm{A}$ and $\mathrm{G}$ are $29 \%$ and $71 \%$, respectively.

Eukaryotic transient expression of R106C and F287L mutants

To further characterize the $A V P R 2$ mutations, eukaryotic expression vectors for R106C and F287L were constructed, expressed in COS-7 cells, and the receptor properties were determined. Using immunofluorescence technique and confocal microscopy, both mutant receptors were found to be present in the cell membrane (data not shown). Figure 5 compares their relative abilities to accumulate intracellular cAMP on treatment with different concentrations of AVP. Both the R106C and F287L mutants were shown to have only approximately $12 \%$ of the ability expressed by the wild type to accumulate intracellular cAMP at $10 \mathrm{nM}$ AVP. 
Fig. 3a-d. Identification of exonic mutations in the $A V P R 2$ gene causing $\mathrm{X}$-linked congenital NDI. Partial DNA sequences of the PCR-amplified products from genomic DNA of affected families show a C-to$\mathrm{T}$ transition at position 316 of cDNA sequences that predicts an arginine-to-cysteine substitution at codon 106 (R106C); b a C-to-A transversion at position 861 of cDNA sequences that causes a phenylalanine-toleucine alteration at codon 287 (F287L); c a C-to-T transition at position 1009 of cDNA sequences that changes the arginine at codon 337 to a stop codon (R337X); d an A/G polymorphism at position 927 of cDNA sequences, which does not alter the amino acid sequence leucine at codon 309 a
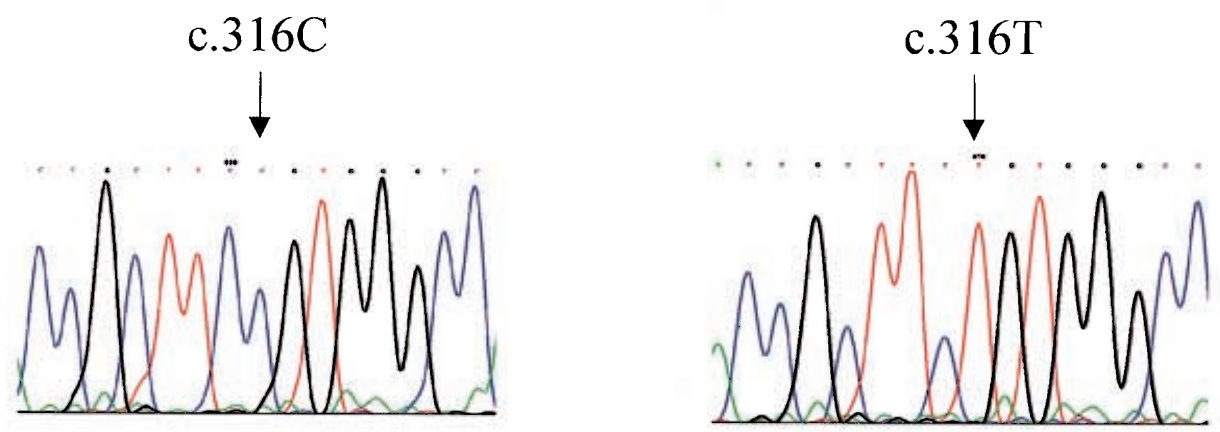

b
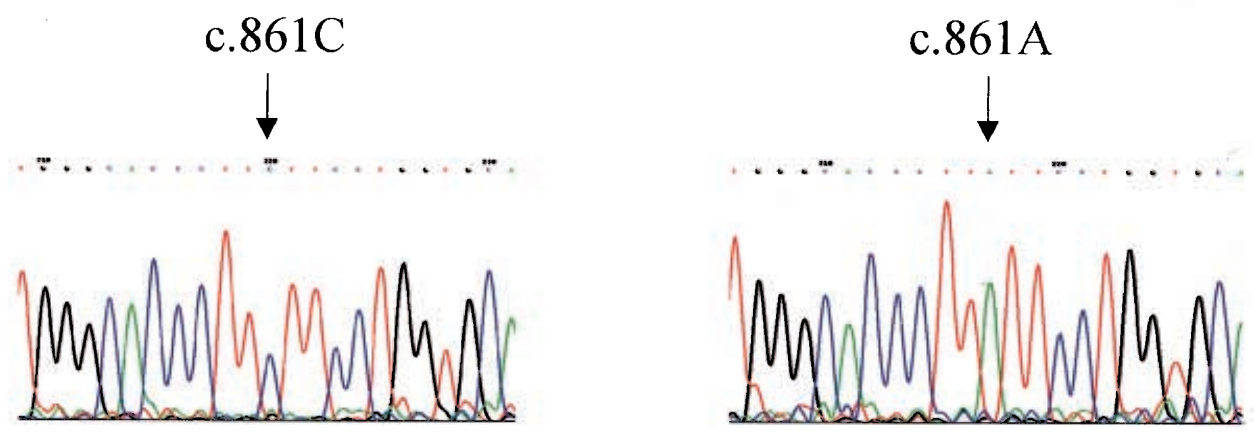

c
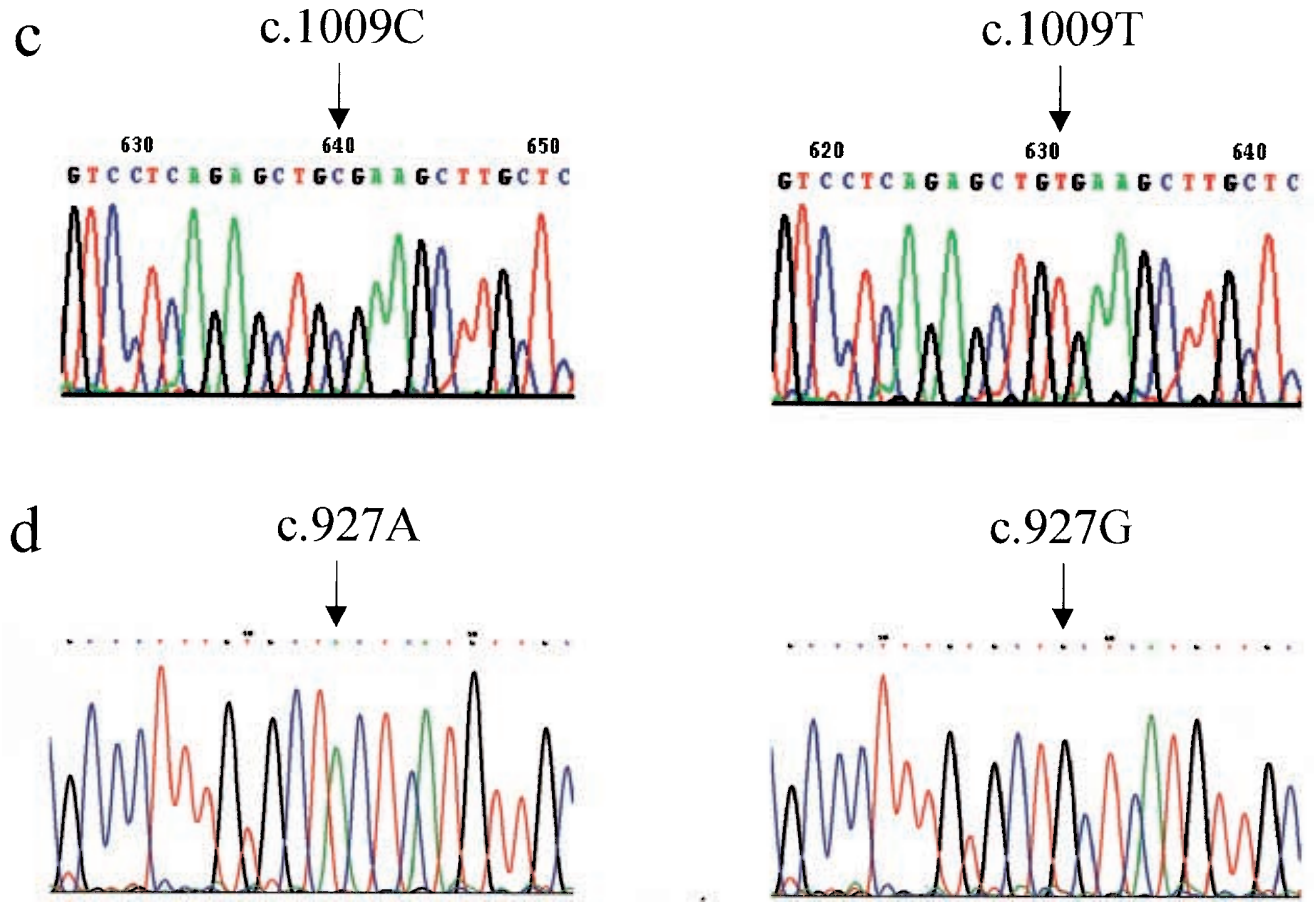

\section{Discussion}

In this paper, three point mutations of the $A V P R 2$ gene are described, which further increases our understanding of the molecular basis of NDI. Two of these mutations (R106C and R337X) have been reported in the literature (Bichet 1994; Knoers et al. 1994; Moses et al. 1995; Wenkert et al.
1994), whereas the third, F287L, is a novel mutation that has not been reported previously. To our knowledge, these mutations are first reported in Chinese NDI patients. The R106C and F287L mutants have not been characterized at a biochemical level previously. R106C and R337X occurred at $\mathrm{CpG}$ dinucleotides, known as hot spots for mutation (Barker et al. 1984). In addition, a common polymorphism was identified in exon 3 of the $A V P R 2$ gene (c.927A/G). 
Fig. 4. PCR-based restriction fragment length analysis used to confirm the AVPR2 mutations R106C and F287L. Upper panel, R106C genotyping for Family 1 . The PCR products $(669 \mathrm{bp})$ were digested with DsaI restriction enzyme. The 187-bp fragments indicated mutant $\mathrm{C}$ allele (see Patients and methods for detail). Lower panel, F287L genotyping for Family 2 . The PCR products $(367 \mathrm{bp})$ were digested with MboII restriction enzyme. The 316-bp fragments indicated mutant $\mathrm{L}$ allele. M1,1-kb DNA ladder (Life Technology, Gaithersburg, MD, USA); M2, $\phi x 174 /$ HinfI marker; $N$, normal individual control; $U$, PCR product without restriction enzyme digestion; $B$, reagent blank for PCR amplification
R106C

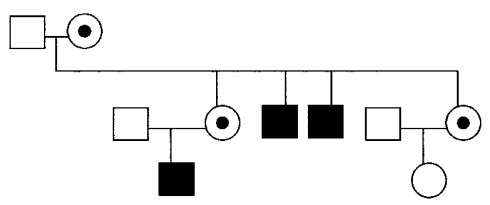

$\begin{array}{lllll}\text { M1 } & \text { N } & \text { U } & \text { M2 }\end{array}$

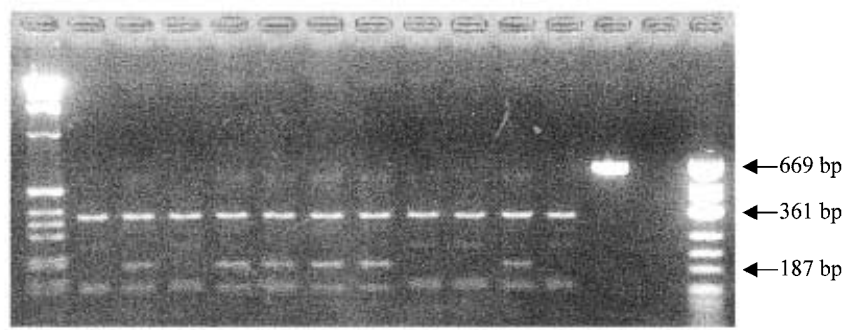

F287L

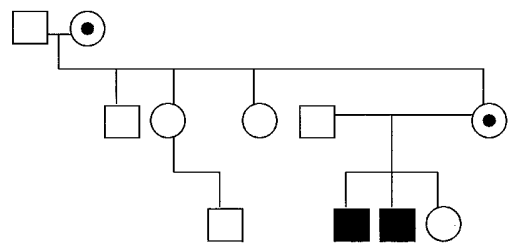

M1

U $\quad$ B $\quad$ M2

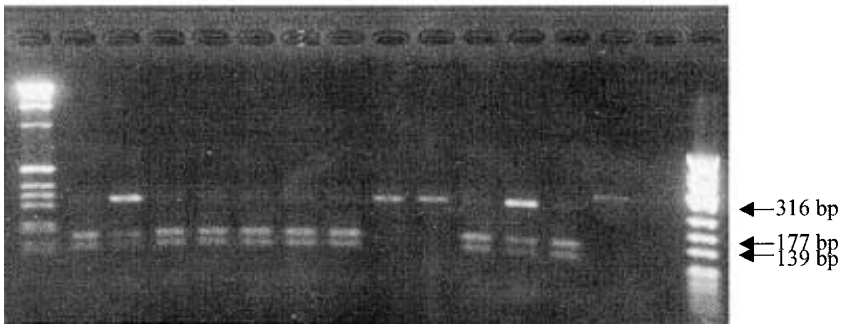

Fig. 5. Functional characterization of the normal and two mutant cDNA, R106C and F287L. Adenyl cyclase activity was determined in COS-7 cells transfected with the cDNA encoding wild type, R106C, or F287L under the stimulation of various concentrations of vasopressin $(A V P)$. The cyclic adenosine monophosphate (cAMP) accumulation was calculated with the base of cotransfected $\beta$ galactosidase activity to correct the variation of transfection efficiency between flasks

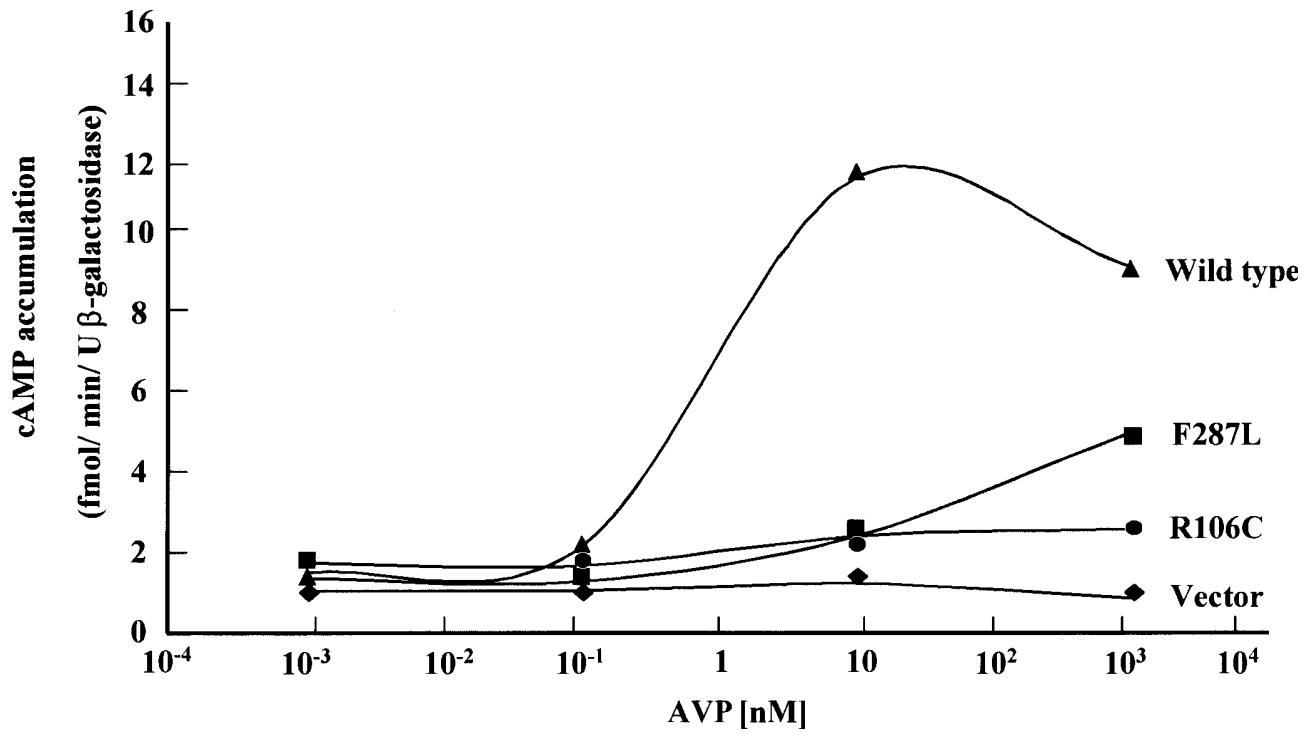


Fig. 6. Schematic representation of the secondary structure of the $A V P R 2$ receptor and the locations of the R106C, F287L, and R337X mutations

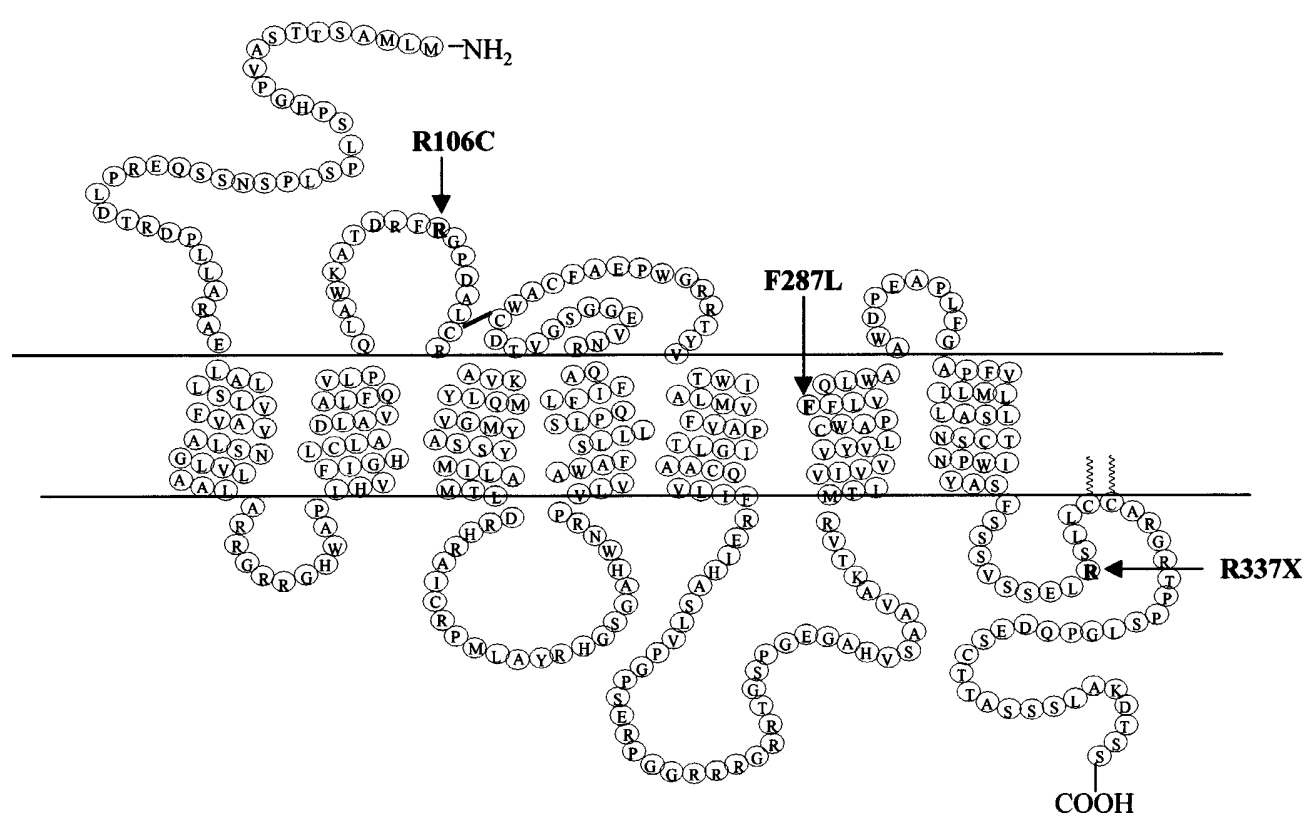

This polymorphism has been reported in other populations (Pan et al. 1992). The positions of these mutations and polymorphisms are depicted schematically in Fig. 6. according to the proposed structure of the V2 vasopressin receptor (Birnbaumer et al. 1992).

The R106C missense mutation might cause an alteration in the region of the disulfide bridge joining extracellular loops I and II, which is important for protein-folding in the $\mathrm{G}$ protein-coupled receptor family, and might consequently impair the binding affinity of the V2 receptor to AVP and decrease the stimulation of adenylate cyclase.

The novel mutation, F287L, occurs at the sixth transmembrane domain and is located next to proline 286. The 286 proline codon is one of the most conserved residues in the $G$ protein-coupled receptor family (Savarese and Fraser 1992) and has been postulated as an $\alpha$-helix breaker. Previously, a P286R mutation was reported to cause NDI. The P286R mutation may generate a kink in the transmembrane helix and affect the receptor function. In this study, the F287L mutation might also affect the helix conformation of the receptor and alter its binding capability.

The severity of clinical symptoms of NDI varies probably because of the heterogeneity of the mutations causing this disorder. The R106C and F287L mutations still have some residual activity and this results in only a partial resistance to the antidiuretic hormone. Patients with these two mutations have moderately severe clinical symptoms. The $\mathrm{R} 337 \mathrm{X}$ produced a mutant protein in which the carboxyterminal 34 residues have been deleted. This ought to severely impair the functional molecule, and patients with this mutation have severe clinical symptoms leading to developmental delay. It should be noted that these severe clinical manifestations are similar to those found in patients with the same mutation reported in the literature (Knoers et al. 1994; Moses et al. 1995). The deleted 34 carboxy-terminal residues contain two possible palmitoylation sites at Cys 341 and 342 that may be important to signal transduction in $G$ protein-coupled receptors if the $\beta 2$-adrenergic receptor is used as a model (O'Dowd et al. 1989).

In summary, three mutations have been identified in the $A V P R 2$ gene that cause X-linked congenital NDI. Not only do these mutations permit precise case identification in their respective NDI families, but they also provide insight into the structure/function relationship of human $A V P R 2$.

\section{References}

Barker DF, Schafer M, White R (1984) Restriction sites containing $\mathrm{CpG}$ show a higher frequency of polymorphism in human DNA. Cell 36:131-138

Bichet DG (1994) Nephrogenic diabetes insipidus. Semin Nephrol 14:349-356

Bichet DG (1998) Nephrogenic diabetes insipidus. Am J Med 105:431442

Bichet DG, Birnbaumer M, Lonergan M, Arthus MF, Rosenthal W, Goodyer P, Nivet H, Benoit S, Giampietro P, Simonetti S, Fish A, Whitley CB, Jaeger P, Gertner J, New M, DiBona FJ, Kaplan BS, Robertson GL, Hendy GN, Fujiwara TM, Morgan K (1994) Nature and recurrence of AVPR2 mutations in X-linked nephrogenic diabetes insipidus. Am J Hum Genet 55:278-286

Birnbaumer M, Seibold A, Gilbert S, Ishido M, Barberis C, Antaramian A, Brabet P, Rosenthal W (1992) Molecular cloning of the receptor for human antidiuretic hormone. Nature 357:333-335

Cheong HI, Park HW, Ha IS, Moon HN, Choi Y, Ko KW, Jun JK (1997) Six novel mutations in the vasopressin V2 receptor gene causing nephrogenic diabetes insipidus. Nephron 75:431-437

Fujiwara TM, Morgan K, Bichet DG (1995) Molecular biology of diabetes insipidus. Annu Rev Med 46:331-343

Hoekstra JA, van Lieburg AF, Monnens LAH, Hulstijn-Dirkmaat GM, Knoers VVAM (1996) Cognitive and psychosocial functioning of patients with congenital nephrogenic diabetes insipidus. Am J Med Genet 61:81-88

Hong CJ, Song HL, Lai HC, Tsai SJ, Hsiao KJ (1999) Methanol/ acetone treatment helps the amplification of FMR1 CGG repeat fragment in dried blood spots from Guthrie cards. Lancet 353:11531154

Kambouris M, Dlouhy SR, Trofatter JA, Conneally PM, Hodes ME (1988) Localization of the gene for X-linked nephrogenic diabetes insipidus to Xq28. Am J Med Genet 29:239-246 
Knoers NVAM, van den Ouweland AMW, Verdijk M, Monnens LAH, van Oost BA (1994) Inheritance of mutations in the V2 receptor gene in thirteen families with nephrogenic diabetes insipidus. Kidney Int 46:170-176

Lolait SJ, O'Carroll A-M, McBride OW, Konig M, Morel A, Brownstein MJ (1992) Cloning and characterization of a vasopressin V2 receptor and possible link to nephrogenic diabetes insipidus. Nature 357:336-339

Moses AM, Sangani G, Miller JL (1995) Proposed cause of marked vasopressin resistance in a female with an X-linked recessive V2 receptor abnormality. J Clin Endocrinol Metab 80:1184-1186

O'Dowd BF, Hnatowich M, Caron MG, Lefkowitz RJ, Bouvier M (1989) Palmitoylation of the human beta 2-adrenergic receptor. Mutation of Cys341 in the carboxyl tail leads to an uncoupled nonpalmitoylated form of the receptor. J Biol Chem 264:7564-7569

Pan Y, Metzenberg A, Das S, Jing B, Gitschier J (1992) Mutations in the V2 vasopressin receptor gene are associated with $\mathrm{X}$-linked nephrogenic diabetes insipidus. Nat Genet 2:103-106

Rosenthal W, Seibold A, Antaramian A, Lonergan M, Arthus M-F, Hendy GN, Birnbaumer M, Bichet DG (1992) Molecular identification of the gene responsible for congenital nephrogenic diabetes insipidus. Nature 359:233-235

Sadeghi H, Robertson GL, Bichet DG, Innamorati G, Birnbaumer M (1997) Biochemical basis of partial nephrogenic diabetes insipidus phenotypes. Mol Endocrinol 11:1806-1813
Savarese RM, Fraser CM (1992) In vitro mutagenesis and the search for structure-function relationships among $\mathrm{G}$ protein-coupled receptors. Biochem J 283:1-19

Schoeneberg T, Yun J, Wenkert D, Wess J (1996) Functional rescue of mutant V2 vasopressin receptors causing nephrogenic diabetes insipidus by a co-expressed receptor polypeptide. EMBO J 15:12831291

Schoeneberg T, Schulz A, Biebermann H, Gruters A, Grimm T, Hubschmann K, Filler G, Gudermann T, Schulz G (1998) V2 vasopressin receptor dysfunction in nephrogenic diabetes insipidus caused by different molecular mechanisms. Hum Mutat 12:196205

Seibold A, Brabet P, Rosenthal W, Birnbaumer M (1992) Structure and chromosomal localization of the human antidiuretic hormone receptor gene. Am J Hum Genet 51:1078-1083

Van den Ouweland AMW, Knoop MT, Knoers NVAM, Markslag PWB, Rocchi M, Warren ST, Ropers HH, Fahrenholz F, Monnens LAH, van Oost BA (1992) Colocalization of the gene for nephrogenic diabetes insipidus (DIR) and the vasopressin type 2 receptor gene (AVPR2) in the Xq28 region. Genomics 13:13501352

Wenkert D, Merendino JJ, Shenker A, Thambi N, Robertson GL, Moses AM, Spiegel AM (1994) Novel mutations in the V2 vasopressin receptor gene of patients with $\mathrm{X}$-linked nephrogenic diabetes insipidus. Hum Mol Genet 3:1429-1430 